\title{
Investment in Infrastructure and Regional Integration: Will Connectivity Reduce Inequalities?
}

Nathalie Fau

The term "connectivity" emerged among Association of Southeast Nations (ASEAN) member states (AMS) during meetings concerning the building of the ASEAN economic community (AEC). Following numerous discussions of this concept at the fifteenth ASEAN Summit in October 2009, the Master Plan on ASEAN Connectivity (MPAC) was adopted in 2010, during the seventeenth ASEAN Summit in Vietnam. The MPAC (2011, pp. 1-3) defines connectivity as the physical, institutional, and people-to-people linkages that comprise the foundation support and facilitative means to achieve the economic, political security and sociocultural pillars toward realizing the vision of an integrated ASEAN Community. It therefore relies on three main pillars: the improvement of the institutional environment so as to reduce tariff and nontariff barriers and favor the creation of a single market in the sea and air sectors; the setting up of legislative measures favoring greater mobility of persons within ASEAN; and finally, the development of transnational transport infrastructures whose aim is to favor connectivity within ASEAN.

According to ASEAN leaders, improved connectivity, especially through transport links, is an essential condition for economic growth in Southeast Asia. Transport links not only provide physical access to resources, but also enable producers to take advantage of opportunities in domestic and foreign markets, leading to economies of scale and specialization. They also enable consumers to have access to a variety of competitively priced goods, encourage investment, promote social integration, and spur trade and economic growth. Furthermore, enhancing ASEAN's connectivity is not only to reduce business transaction cost, time, and travel costs, but also to connect the "core" and the "periphery" in ASEAN (Basu Das, 2013 , p. 3), thus distributing the benefits of multifaceted growth wider in the region and reducing the development divide in ASEAN.

ASEAN's connectivity plan therefore takes as its starting point the hypothesis that there exists an obvious link between building infrastructures, the opening up of territories and their inclusion in newly established networks, and economic development. Due to this fact and according to ASEAN leaders, the upgrading of infrastructure, the construction of new infrastructure, and the harmonization of the regulatory framework would significantly narrow the development gap within ASEAN. It is precisely this hypothesis that this chapter is questioning, by focusing especially on the MPAC's development projects for land (road and rail) and sea transport infrastructures. After presenting the main directions taken by the MPAC and the tools used to decrease territorial inequalities regarding provision of infrastructures, this chapter attempts to assess on different scales (regional, subregional, and local) the regions that have gained or lost since the MPAC was implemented and to explain the reasons for these disparities. 


\section{The MPAC's Infrastructure Development Plan: A Project Designed to Combat Inequalities}

The quality of infrastructures plays a crucial role in improving the attractiveness, connectivity, and accessibility of a country. However, the Logistics Performance Index (LPI), which measures not only the quality of infrastructures but also the efficiency of customs services or the speed of deliveries, emphasizes continuing wide discrepancies between ASEAN member states. The 2014 report produced by the World Bank indicates that ASEAN countries come into all categories: from logistic-friendly (Singapore and Malaysia occupy the fifth and twenty-fifth world positions, respectively) to logistic-unfriendly (Laos and Myanmar), via the status of Constant Performer (Thailand, Vietnam, and the Philippines) and Partial Performer (Cambodia). The range could not be wider, and one of the MPAC's main objectives is therefore to reduce inequalities in infrastructure development.

\section{Improving and Interconnecting Transport Networks within ASEAN}

The transport infrastructure development plans drawn up in the MPAC continue on the same main lines as previous plans: the Successor Plan of Action in Transport, 1999-2004; the ASEAN Transport Action Plan (ATAP), 2005-2010; and the ASEAN Strategic Transport Plan (ASTP), 2011-2015.

In the field of land infrastructure (MPAC, 2011, pp. 11-13), the two most important projects are the ASEAN Highway Network (AHN) and the Singapore-Kunming Rail Link (SKRL). In all ASEAN countries, the improvement of road infrastructure is a national priority, designed increasingly in coordination with networks in neighboring countries. The AHN project, ratified in 1999, is a component of the Trans-Asian Highway. The aim is to construct by 2020 a network of 23 transnational roads, with a total of 38,000 kilometers, conforming to Class I standards, and to build the missing sections, mainly in Myanmar, Laos, Vietnam, and Cambodia. However, in spite of an extensive rail network, mostly dating from the colonial period, ASEAN has been slow in establishing a regional development policy for the rail sector. In the 1960s, in the context of the Trans-Asian Railway (TAR), the United Nations had proposed to support the building of a railway linking South China to Malaysia via Indochina. However, the network deteriorated rapidly through lack of maintenance and remains underexploited today for both passenger and freight transport. The SKRL project, proposed during the fifth ASEAN summit in December 1995, is a branch of the Pan-Asia Railway Network. Its aim is to integrate, modernize, and renovate existing rail networks and build missing sections in order to link Kunming, the capital of Yunnan in China, to Singapore, via railways running along both sides of the Indochinese Peninsula: in the east, the originally planned line passes through Kunming, Hanoi, Ho Chi Minh City, Phnom Penh, Bangkok, and Singapore; in the west, the line, whose construction is much further ahead, links Kunming to Singapore via Mandalay, Rangoon, and Bangkok. The missing sections are concentrated in Cambodia, where the only railway line working at present links Phnom Penh to Sihanoukville.

It is certainly in the sea transport sector that inequalities within ASEAN are the greatest. The flow of containers is concentrated on three ports located on the Malacca Straits: in 2013, Singapore, Port Klang (Malaysia), and Tanjung Pelepas (Malaysia) handled, respectively, 32.57 million, 10.35 million, and 7.7 million evps, between them accounting for 50.63 evps, or more than half the total traffic in Southeast Asia (56.6 percent), and 100 percent of the transshipment 
flow, estimated at 40 million evps in 2013 (Fau, 2014). Similarly, the Liner Shipping Connective Index published by the World Bank, which enables a country's connectivity in the world network of regular sea transport to be measured, emphasizes very great disparities within ASEAN. For the period 2009-2013, three groups of countries appear clearly: the first group is at the top of world ratings, with Singapore (106.9) and Malaysia (98.2); the second is close to average with Vietnam (43.3) and Thailand (38.3); and the last, very poorly connected to world shipping routes, includes both archipelagic states such as Indonesia (27.4) and the Philippines (18), and countries that have turned their backs on the outside world for many years, such as Myanmar (6) and Cambodia (5.3). In order to reduce these inequalities, the MPAC (2011, pp. 13-14) plan has designated 47 priority ports for improving the ASEAN sea transport network. This plan has two main objectives: promoting maritime links between the countries of insular Southeast Asia and improving connectivity between continental and maritime areas. One of the major projects is to extend to the whole of ASEAN the Roll-on/Roll-off transport system that has already been tested in the Philippines and which has helped reduce unequal development in the archipelago.

Finally, in comparison to previous ASEAN transport plans, the MPAC's innovation is to promote the development of intermodalism (ASEAN, 2011, p. 41). The improvement of connectivity within ASEAN cannot be restricted to a single form of transport. The very definition of the concept of "connectivity" by a geographer specializing in networks is the property of a network to offer alternative routes between places, either by a spatial mesh or by developing several different means of transport along the same route, or by both. The MPAC therefore affirms the necessity of improving links between means of transport. For example, the port is considered as an essential component in the construction of land corridors. Ports are "gateways" enabling the connection to the exterior of flows of goods using land routes structured by hubs, which collect and distribute them along these corridors. So, since the 2000s, transport investments have diversified in comparison to the previous decade (Taillard, 2014): not only roads and bridges, but also local feeder roads and ports connect them to the main maritime routes. They also include railways, airports, and river navigation for industrial development and tourism. These investments also largely surpass the field of transport and extend to what may be termed "interconnectivity," including interconnections of electrical and telecommunications networks, construction of gas and oil pipelines, and creation of cross-border free development zones.

\section{Concentrating, Regionalizing, and Opening Up to the Outside World: Spatial Strategies of Infrastructure Development}

Apart from a sector-by-sector approach, the MPAC is also developing a spatial strategy for infrastructure establishment: concentrating flows of traffic by building economic corridors, regionalizing planning via the identification of each subregion's specific demands and needs for infrastructures, and finally, opening up with a view to interconnecting ASEAN transport networks with those in neighboring Asian countries.

Economic Corridors: Not Just Transport Routes, but Also Tools for Connecting Industrial Centers to Peripheral Areas

The building of economic corridors is not specific to Asia. In fact, the Asian Development Bank (ADB) and the MPAC have taken development tools developed by the United Nations and the 
World Bank during the 2000s and applied them to ASEAN. In 2002, the United Nations also launched the project entitled "Capacity-Building in Developing Interregional Land and Landcum-Sea Transport Linkages," whose aim is to identify, in each world region, the interregional transport links that would contribute to better integration and promote economic development. According to United Nations planners (ESCAP, 2009), transnational corridors are the new geographical space where urban development and competition strategies are deployed. It is not just a question of linking cities via more efficient communication routes, either by creating them or improving existing ones, but of developing a new type of multipolar transnational space, connecting existing and emerging urban regions (Bender, 2001). In theory, this does not concern megalopolises, but should create new external conditions that many large and medium-sized cities can take advantage of, especially in interior, border regions or in outlying pioneering areas. The function of these corridors is to favor the setting up of new productive activities, thanks to improved accessibility, the development of energy infrastructures, and the capacity for processing local products.

This economic corridor strategy was also directly influenced by the ERIA (2010; Kimura, 2013) research institute (Economic Research Institute for ASEAN and East Asia). During the 2010 East Asia Summit, ERIA proposed a transport and logistic infrastructure development project for ASEAN. This plan took as its starting point the unequal development of ASEAN countries, including development within the countries themselves; it divided ASEAN economic areas into three groups, classifying them according to the level of economic development: the "Tier 1" areas are zones with a high concentration of industrial production (Singapore, Selangor, Bangkok, Hanoi, Jakarta), but whose excessively large conurbations and risks of overcrowding may pose a threat to their capacity for innovation; "Tier 2" areas are involved in the industrial process but their advantages, location, and population density could all be more thoroughly exploited (Phnom Penh, Vientiane, Medan, Yangon, Danang, Davao, Makassar); finally, the "Tier 3" areas are marginal to industrial development and still confined to the primary sector (Dawei, Poipet, and the mountainous regions of Cambodia, Laos, and Myanmar). Starting from the observation that the industrial process can be broken down into several stages, each independent of the others, and each with its own technoeconomic characteristics, ERIA emphasizes that it is perfectly possible to segment the industrial process according to the "comparative advantages" of each region. However, this mode of operation, which has already been used for years in East Asia in the automobile, electronics, textile, and agro-industrial sectors, could be extended by linking "Tier 1," "Tier 2," and "Tier 3" areas with potential for industrial development more systematically, by means of high-quality transport infrastructures. Also, in order to avoid an excessive concentration of investments along a single route, ERIA recommends a mesh of Southeast Asian territories via several intersecting corridors and an extension of the corridors to neighboring countries.

\section{Infrastructure Development Plans Designed for Subregional Areas}

To start with, the demarcation of economic corridors was not designed on a trans-ASEAN scale, but on that of three subregions (ASEAN, 2011, p. 29): the Greater Mekong Subregion (GMS) regroups the five countries of the Indochinese peninsula (Cambodia, Lao PDR, Myanmar, Thailand, and Vietnam) and two provinces of southern China (Yunnan was joined by Guangxi in 2004), the Indonesia-Malaysia and Thailand Growth Triangle (IMT-GT), The Brunei Darussalam, Indonesia, Malaysia, and the Philippines-East ASEAN Growth Area (BIMPEAGA). These subregional economic zones (SREZs), created in the 1990s under the names of 
growth triangles or polygons, originally aimed to promote cooperation and regional synergy by exploiting the complementary features of the groups of territories. These SREZs, many of which existed only on paper, attracted attention again with the ADB's launch of its development strategy for transnational transport routes, later renamed "economic corridors" (Fau, 2014a).

It is in continental areas, in the GMS, that this new model of economic development has been the most extensive (ADB, 1999; Taillard, 2014). The ADB's aim was, originally, to rebuild roads in order to favor the resumption of economic relations between countries in the peninsula, thus abolishing the isolation caused by the colonial period and the Cold War in favor of new regional integration. During the period 1992-2002, the ADB supported the creation of five economic corridors, both meridian and transversal; those providing the greatest structure, and the most ambitious, were the North-South corridor running from Kunming, in Yunnan, to Bangkok, in Thailand, after following the Chao Phraya basin and crossing four countries (China, Myanmar, Laos, and Thailand); and the East-West corridor linking both seaboards of the peninsula, and Myanmar with Thailand, Laos, and Vietnam. It should also be noted that the southern corridor linking the capitals of Bangkok, Phnom Penh, and Ho Chi Minh City should play an increasingly important role, especially since an extension is planned to Tavoy in Burma. In the second stage (2002-2014), the network of corridors has become more varied and complex with the inclusion in 2004 of another Chinese province, Guangxi, and that of rail infrastructure. There is now an "increasing interface between GMS and ASEAN transport connectivity initiatives. For instance, some of the sections of the AHN coincide or interface with the road projects in the GMS Transport Sector Strategy (2006-2015), particularly in the CLMV countries (e.g., Siem ReapStung Treng in Cambodia, Hanoi Haiphong in Vietnam). Furthermore, two GMS railway projects in Cambodia and Vietnam form part of the SKRL” (MPAC, 2011, p. 30).

In insular Southeast Asia, the ADB promotes the specific development of maritime corridors as well as projects for improving land infrastructure. The ADB (2007) has also included in its new development plan for IMT-GT for the period 2007-2011 the creation of three transversal economic corridors, each one linking a pair or a trio of ports: Songkhla-PenangMedan, Melaka-Dumai, and Ranong-Phuket-Aceh. In order to encourage links between these major ports, priority has been given to the improvement of their infrastructures such as fast ferries and roll-on roll-off (RO-RO) ships. For example, the BIMP-EAGA plan for the period 2012-2016 (ADB, 2012) defines as one of its priorities the creation of an RO-RO network between ports designated as having priority in the MPAC: Glan-Tahuma, Zamboangan-Bongao, Tawi-Tawi, and Bongao-Sandakan. It also introduces the creation of two economic corridors: the West Borneo Economic Corridor (WBEC), which is, in fact, divided into three transnational land transport routes, and the Greater Sulu-Sulawesi Corridor (GSSC), which is, on the contrary, almost exclusively a maritime corridor linking North Sulawesi in Indonesia, Sabah in Malaysia, and Mindanao and Palawan in the Philippines.

\section{Improving Connectivity with Neighboring Non-ASEAN Countries}

Even though the main aim of the MPAC is to improve connectivity within ASEAN member states, there is also interest in improving connectivity with neighboring countries, especially China, India, and East Asian countries (Kimura and Umezaki, 2011). The objective is to affirm ASEAN's "centrality," that is, the region's unity in the face of the economic power of its neighbors. ASEAN wishes to use its position of intersection between Asian infrastructures to neutralize the influence of its powerful neighbors by counterbalancing them. Thus, in order to 
reduce the growing influence of China in connectivity plans for Southeast Asia, the MPAC (ASEAN, 2011, p. 41) supports the Mekong India Economic Corridor (MIETC) initiative. This plan proposes to build two routes: one sea route, linking Bangkok to Chennai in India, via Dawei in Burma; and one land route, linking Moreh, in the north of India, to Mae Sot in Thailand, via Bagan in Burma. Although the sea route is a legitimate part of the MPAC project since it is an extension of the Southern Economic Corridor proposed by the ADB for the GMS, the land element is more of an answer to the Indian government's worries, since it aims at disclosing northeast India.

\section{Is Continental Southeast Asia Receiving too Much Attention, at the Expense of Maritime Southeast Asia?}

Although the division into subregional zones aimed to make it easier to determine priorities in needs for infrastructure, it may also have contributed to a divide in ASEAN between continental and maritime areas. Several elements support this hypothesis: unequal involvement of the ADB in the development of infrastructures between maritime and continental areas and the growing presence of China in building and financing GMS infrastructures. These two points emphasize that there is at present a real struggle between Asian powers to control the development of transport infrastructures within ASEAN.

\section{Unequal Involvement of the ABD between Maritime and Continental Areas}

The Asian Development Bank played an unequal role in the implementation of the integration process in the GMS and in the IMT-GT; whereas it is central in the first case, it is highly marginal in the second. Since 1992, the ADB has promoted and accompanied the creation of the GMS in order to favor increased commercial exchanges in the peninsula. Its involvement and commitment have played a central role in making this initiative credible both to the countries involved and to financial backers. On the contrary, the ADB was a late arrival to the IMT-GT project, and it only became involved in 2007, whereas this cooperation zone was created in 1993 following a trilateral agreement among Indonesia, Malaysia, and Thailand.

Also, the ADB's plans to build economic corridors linking both sides of the Malacca Straits seem to be a clumsy and unsuitable transposition of tools tested in the GMS. Studies conducted by the ADB, but also by researchers such as Eswaran (2008) and Banomyong (2006) have shown that maritime corridors always perform less well than land corridors. They also revealed that the weakest link in the economic corridors of IMT-GT were transversal maritime corridors linking the two sides of the Straits of Malacca. However, this relatively low performance of maritime corridors, far from revealing the absence of traffic between the two shores, shows in fact that it is not very appropriate to resort to "economic corridors" to evaluate the quality of connectivity in the Malacca Straits. First, as stressed by Ruth Banomyong (2006), the corridors linking Malaysia and Sumatra are not multimodal transport corridors but more "traditional or archaic corridors" and the bilateral maritime trade between the two neighboring countries is being handled by nonconventional vessels (barter trade movement, fishing vessels but also illegal vessels). Furthermore, the fluid and relatively unconstrained nature of the maritime zone leads to a spatial organization in which the twinned ports are not only connected with each other, they also multiply the exchanges across the straits with ports located farther down in the port hierarchy, in a network that is more complex than a simple "hub and feeder" 
relationship (Fau, 2014b). In this context, a study on the connectivity of maritime corridors should take this diversity of sea traffic into account.

Finally, although the ADB has been responsible for both the GMS and growth triangles in the Malacca Straits, it is surprising to note that the infrastructure connection between these two transnational projects has never really been considered. Nevertheless, the two projects could be in competition with each other. For example, the projected oil and gas pipelines linking the port of Kyaukphyu in Myanmar with Kunming in China are directly intended to short-circuit the hitherto unavoidable passage via the Malacca Straits (Kimura, 2011).

Thus, the ADB's decisions do seem to systematically favor the development of infrastructures in the GMS. Without directly penalizing maritime Southeast Asia, they do not promote either improved internal connectivity or improved links with continental Southeast Asia.

\section{The Weight of China in the Financing of GMS Infrastructures: A Divisive Factor within ASEAN?}

According to Geoff Wade (2010), the development of land transport networks contributes more to improving connectivity between continental Southeast Asia and China than to intra-ASEAN connectivity. The very significant tropism exerted by the southern provinces of China on the countries of the GMS region may even eventually lead to a division between maritime and continental Southeast Asia. If we consider the recent evolution of railway projects proposed by China in the GMS, we can note that they bear no relation to those proposed by the MPAC. Its projected high-speed line between Kunming and Bangkok, unveiled in 2010, does not run along the east and west coasts of the Peninsula: it crosses it in its central part, benefiting Laos and Thailand, but disadvantaging Vietnam and Cambodia (Taillard, 2014). Also, the building of two railway lies, one in the west toward Burma and the other in the east toward Vietnam, is aimed less at improving intra-Asian connectivity than connecting neighboring countries to the Chinese network.

As far as the Laotian government is concerned, it will certainly have to choose between the Chinese project, a 421-kilometer-long high-speed link between Vientiane and Kunming, and the project promoted by the ADB as part of the SKRL: a 220-kilometer-long line linking Laos to the Vietnamese border. To consider carrying out both projects at the same time seems unrealistic in view of the extremely high construction costs in a country that does not have even a basic road and railway system: US\$7 billion for the Chinese project and US\$5 billion for the ADB project, making a total greater than Laos's annual GNP. However, the Laotian government has already signed a contract with a Malaysian company (Giant Consolidated) to build its section of the SKRL, and taken out a loan from Peking via the Exim Bank for the link between Vientiane and the Chinese border. Laos's ambition to become a regional transport node is not risk free, and could even mortgage its future development. Since the Chinese railway company, which was supposed to finance 70 percent of the project, has finally withdrawn, the financial risk is now the sole responsibility of the Laotian government. However, "the loan is guaranteed, in addition to the future income from the railway and the assets linked to it, by Laotian royalties derived from joint Lao-Chinese mining ventures (exploiting gold, copper, potassium and in future bauxite and iron)." In these conditions, the IMF and the ADB drew the attention of the Laotian government to the risks of such an investment, which would burden most of its mining resources with debt for 38 years until the debt was repaid. This awkward situation for Laos directly emphasizes how little ASEAN invests in infrastructure: the ASEAN Infrastructure Fund (AIF), created by 
ASEAN with the active support of the ADB in 2002, does not allow at this stage for any funding in the rail sector, with the energy sector taking priority.

But is it really possible to differentiate between continental Southeast Asia, said to be in China's orbit, and a more independent maritime Southeast Asia? Until very recently, Chinese infrastructure projects were concentrated on the GMS; however, in 2013, during an official visit to Indonesia, and during the sixteenth ASEAN+China summit in Brunei, China launched the "Maritime Silk Road" (MSR), a term referring to the fifteenth-century maritime expeditions led by Admiral Zheng He in Southeast Asia and the Indian Ocean, as far as the Persian Gulf. The advantage of this term is that it has a peaceful connotation, since these voyages of discovery did not lead to overseas expansion but to the development of trade. The promised aim of the MSR is thus to strengthen maritime cooperation between China and ASEAN countries. The ChinaASEAN Maritime Cooperation Fund should enable the financing of port infrastructure construction projects, but also research programs concerning the maritime environment and fishing, and collaborative security projects in the South China Sea and the Malacca Straits. There are still few concrete projects but the MSR should develop the specificity of maritime links between China and insular Southeast Asia.

\section{Development of Connectivity in Southeast Asia: Competition between the Asian Powers}

The Chinese government is not the only one wanting to control the development of transport routes in Southeast Asia. The GMS corridor linkage has whetted the appetite of major peninsular and Asian powers to assume control or leadership of these transnational integration dynamics (Taillard, 2014). The rivalry between Thailand and Vietnam for the control of the peninsula is thus revealed by investment and infrastructure in neighboring countries in the context of competitive subregional cooperation: the Irrawaddy, Chao Phraya and Mekong Economic Strategy (ACMES) and Cambodia-Lao PDR-Vietnam Development Triangle show the rivalry between Thailand and Vietnam to impose their political and economic leadership on Lao PDR and Cambodia. Similarly, the integration of Thailand and Myanmar into the Mekong-Ganges program enables their respective governments to counterbalance the power of China. Furthermore, Japan is the largest aid donor for CLMV countries. Its official Development Assistance (ODA) supports a plethora of infrastructure developments throughout the region. Japan is also the largest provider of funds for the GMS program. In the GMS, there is growing competition between Chinese hegemony over the meridian corridors and Japan's dominance over transversal corridors: leaving China an open field on the meridian North-South corridor, Japan had supported the Cambodia-Laos-Vietnam Triangle at a very early stage. It has invested mainly in transversal corridors, the East-West and Southern ones. This can also be seen in the rivalry among Singapore, Malaysia, and Indonesia to capture business from the flow of container ships and container trade in the Straits of Malacca (Fau, 2014). The competition among ports along the Straits to attract shipping lines and cargo is rising and this prevents the possibility of developing port complementarities. The straits are seen as an international transport route rather than an internal sea, which is a serious handicap to the development of connectivity between the two shores. Due to this fact, unlike intrastraits traffic, where maritime connectivity is quite slight, external connectivity, that is, connectivity with the international market, is very good. 


\section{Which Countries Have Benefited Most?}

In order to estimate the economic impact of infrastructures - whether already built or plannedERIA (2010) created in 2007 a Geographical Simulation Model (GSM) taking into account 956 units in 13 countries. The GSM measures, corridor by corridor, with the possibility of combining several, this impact "in percentage of incremental gross regional products, cumulative over ten years after the improvement of logistics links, vis-à-vis the benchmark case." Once all the corridors are taken into account, the GSM shows that Myanmar is the greatest beneficiary (145.8 percent), followed by Vietnam (114.6 percent), the Lao PDR (99.3 percent), Thailand (98.6 percent), and Cambodia (97.9 percent). The countries of maritime Southeast Asia show lesser gains, especially the three rated last: Indonesia (85 percent), the Philippines (73.4 percent), Malaysia (64.4 percent), Singapore (29.2 percent), and Brunei (2.7 percent). These results show that, with the exception of Thailand, it is the low-income countries that should benefit and that the corridors should reduce inequalities in growth within ASEAN.

Although these projections provide us with elements enabling us to measure the impact of corridors, they take it for granted that the ASEAN connectivity plan is accepted with equal enthusiasm throughout ASEAN countries. However, as Bambang Susantono (2013, p. 63) very rightly points out, citing the specific case of Indonesia: "it is natural for regional connectivity to be perceived with skepticism from several countries because of the perceived threats of a potential resource drain. Regional connectivity may come with positive and negative implication. (. . .) It is possible that the larger economies will crowd out the smaller economies." The MPAC is not accepted in the same way everywhere, and while some governments see it as a new opportunity, others think of it as a real threat. Beyond the superficial consensus on the necessity of improving connectivity within ASEAN, the degree of involvement of the different governments can be measured by analyzing the extent to which the planning policies of ASEAN countries have been adapted to the MPAC. According to case studies performed by researchers from the "Transnational Dynamics in Southeast Asia, the Greater Mekong Subregion and Malacca Straits Economic Corridors" research (Fau, Khonthapane, Taillard, 2014), it is possible to distinguish between three types of ASEAN countries.

Indonesia is representative of the first type: countries favoring the improvement of internal, rather than regional connectivity. It is thus symptomatic that in the Master Plan for Acceleration and Expansion of Indonesia Economic Development, 2011-2015 (Mp3ei), the Indonesian government introduced economic corridor projects without really taking into account those proposed by the ADB (Charras, 2014). For example, in the Indonesian plan there is no mention of the two transversal routes proposed by the ADB to link the two sides of the Straits of Malacca in the frame of IMT-GT. In Sumatra, the strategy aims primarily at national integration. Thus, the flagship project will entail building a bridge linking Java to Sumatra across the Sunda Strait. In fact, as mentioned by M. Charras (2014, p. 235), there is little prospect for the development of connectivity between the eastern part of Sumatra and Malaysia as long as Sumatra is not physically linked to Java.

The second type of country, represented by Myanmar, is the exact opposite of the first: it favors the development of regional integration infrastructures without taking account of the spatial logic involved in developing its own territory. Burma's port development policy is very significant in this regard. In order to meet regional demand for ASEAN access to the Indian Ocean, several building projects for deep-water ports are under consideration: Sittwe, Kyaukpyu, 
and Dawei (Htun et al., 2011; Vignat, 2014). In all three cases, it is a case of exploiting Burma's position as a veritable land bridge between ASEAN, China, and India, thus dispensing with the obligation of passing through the Malacca Straits. However, the three projected deep-water ports are very poorly connected to Yangon and Mandalay, where infrastructures are defective in many sections (Min and Toshihiro, 2012). The northwestern corridor (Kunming-Mandalay-Yangon) is also more significant in the context of China's development policy than that of Myanmar: it enables China to secure its access to the Indian Ocean and vary its energy supply routes, and only the Mandalay-Yangon section, which is the backbone of the territory controlled by the Burmese authorities, has any real meaning for Burmese territorial organization still dominated by armed conflicts in outlying areas. However, it should be noted that this is more or less a unique case and is mainly the result of the Burmese government's desire to improve international legitimacy, and get round the sanctions imposed by the West in 1997.

The third type, represented by two extreme cases, Laos and Thailand, is that of countries that take advantage of this improvement in regional connectivity to strengthen their economic weight. The inclusion of Laos in the GMS is a veritable strategic reversal: for a long time a landlocked buffer state, separating potential enemies during the Cold War period, its position is now that of an intersection on the scale of the peninsula. Laos is the country that has most closely taken into account the proposals of the ADB in its national plan, partly on account of its limited financial resources, but especially because three economic corridors cross its territory. The objective shared by the ADB and the Laotian government is to extract Laos from its enclaved position by placing it at the center of the subregional transport network (Pholsena, 2014.). Similarly, since 2001, the Thai government is guided by its ambition to make this country a logistic hub for mainland Southeast Asia and South China. Located in the center of the Greater Mekong Subregion, Thailand is improving its connectivity with Myanmar, Laos, and Cambodia by directly cofunding with other financial backers (China or the ADB) the road sections of economic corridors crossing their territories (Banomyong et al., 2011). It is also the main beneficiary of the Kunming-Bangkok meridian route, but also of the extension of the GMS corridors to India.

\section{Which Local Areas Have Benefited Most?}

Does Southeast Asia's strategy of creating a web of transport routes help to strengthen already existing hubs, or, on the contrary, does it favor the emergence of new ones? In the context of economic corridor creation, the ABD insists on the major role of two types of nodes structuring the internal working of the corridors: corridor heads on the one hand, and border cities on the other.

\section{Corridor Heads: Strengthening of Old Centers and Emergence of New Ones}

Regarding corridor heads, it is interesting to note that they are not only well-established centers but also emerging ones. The North-South corridor heads (Kunming, Bangkok, and Hanoi) and the southern ones (Bangkok and Hô Chin Minh) are metropolises of several million inhabitants, of regional importance, long integrated into trade networks. Formerly isolated from each other, these metropolises are increasingly linked together, thus favoring a synergic development. Their inclusion in the GMS contributes directly to strengthening their regional weight since their new functions include favoring links, not only between the different corridors, but also between continental and maritime transport flows. Ch. Taillard (2014) has estimated their new respective 
weights by identifying the number of economic corridors controlled by each of these metropolises. Bangkok and Kunming, at the intersection of at least three corridors, are well ahead of the others. The East-West corridor, on the other hand, favors the emergence of new centers, designating as corridor heads cities of lesser importance on the regional scale, such as Moulmein or Danang. The city of Da Nang, located in the center of Vietnam, was long curbed in its economic development by the country's double metropolization around the northern and southern capitals, Hanoi and Hô Chi Minh-City. Its new regional role controlling the East-West corridor and the improvement of links with Bangkok have enabled it to acquire international functions hitherto monopolized by the other two Vietnamese metropolises.

Among these new hubs, we should mention the emergence of new ports. The development of land infrastructures in the Greater Mekong Subregion should eventually exert a direct influence on the reorganization of port facilities in Southeast Asia. Two of the economic corridors provide a link between the two seaboards of the peninsula: the first, the East-West corridor provides a 1,450-kilometer-long link between the Burmese port of Moulmein and the Laotian port of Danang, after crossing Myanmar, Thailand, Vietnam, and Laos; the second, further south, passing through the peninsula's three southern capitals (Bangkok, Phnom Penh, and Hô Chi Minh-City) will be extended in the future, with Thai funding, to the west, as far as the Andaman Sea and Dawei (Tavoy). Also, the Kunming-Mandalay-Rangoon corridor, one of whose branches turns off to Sittwe, enables southern China to access a new maritime outlet. In this context, the western seaboard of the peninsula has a new role to play by capturing the flow of container transport normally transiting via the Malacca Straits (Htun et al., 2011; Banomyong et al., 2011).

\section{Border Zones}

The originality of the ADB and MPAC programs is, however, to promote the integration of corridors via the valorization of border zones, in spite of their often marginal positions on a national scale. The main points of this strategy are: the multilateral Cross Border Transport Agreement (CBTA) and the planning and funding of free zones or special economic zones in border areas, as well as direct financial support for improving infrastructure in border cities located on corridors.

\section{Implementation of the CBTA: An Advantage or a Handicap for Border Areas?}

After the Asian crisis, the ADB made it imperative to link the reconstruction of transport infrastructure to the signing of specific free trade agreements, corridor by corridor, anticipating the global ASEAN Free Trade Agreement (AFTA) that will be applied in 2015 (Taillard, 2014). The CBTA, finalized in 2007 and supposed to become effective in 2010, seeks to standardize traffic and customs procedure among all countries and initiate single-stop inspections at GMS border crossing to reduce transport time (Ishida, 2013b). The CBTA therefore aims to facilitate border crossings and reduce transshipment costs. However, Ishida indicates that rules and regulations such as the CBTA are in place but have not been completely implemented. This may require a lot of effort in terms of implementation as some countries still cannot fulfill their contractual obligations. Signing or even ratifying an international agreement does not mean immediate implementation.

Apart from this observation, we may also wonder whether the generalized implementation of the CBTA may not in the long run penalize border zones. A freer flow of 
transnational traffic may change these areas into transit areas and activities directly linked to border trade may become obsolete: truck transshipment centers, warehouses including bonded warehouses, branches of logistics firms, or duty-free shops. Also, as observed by M. Ishida (2013b), when the integration of GMS countries becomes effective, industries will be more likely to be set up within neighboring countries, close to their major national centers, thereby deserting the border areas that are often less competitive and less well equipped in infrastructure.

\section{Unequal Impact of SEZ on Borders}

In the conclusion to his book, Masami Ishida (2013a, pp. 229-332) rightly emphasizes that the policies of middle-income countries/regions and Cambodia, Laos, and Myanmar are completely different with regard to their objectives in developing border areas. Although the former group aims to stimulate the growth of peripheral areas in order to reduce economic inequalities within the countries concerned, the latter group aims mainly to take advantage of the proximity of their rich neighbors to favor national economic growth and reduce the poverty level. Consequently, the development models of border areas are completely different.

On the Cambodian and Laotian borders, the two dominant forms of economic development are casinos, which proliferate since they are banned on the opposite side of the border and Special Economic Zones (SEZ), which try to attract foreign investors by offering exemptions from taxes and social charges without equivalent in Asia (Bafoil, 2013): a very low minimum wage ( $\$ 43$ per month in Laos and $\$ 62$ in Cambodia in 2012), numerous tax exemptions for firms or extremely long leases (99 years for developers of these zones in Cambodia). In both cases, these zones operate more as enclaves than as growth center, and, far from favoring a spillover of growth, they are completely disconnected from their regional environment. In most cases, there is no connection between infrastructures built in these zones and those in the region. Thus, all the SEZs in Poipet, on the Cambodia/Thailand border, get their electricity supply from the Thai side, export their products through the port of Laem Chabang rather than that of Sihanoukville, and possess only a limited infrastructure network, since the roads and the border zone are financed by the only private developer of the SEZ and not the Cambodian government (Shiraishi, 2013). As for the casinos, they mainly fuel an illicit crossborder economy. The city of "Golden Boten," located in the "golden triangle" area on the China/Laos border, is thus a Chinese enclave on Laotian territory completely dominated by a Chinese drug baron Ling Mingxian. It is not only a favorite tourist destination for the Chinese but also a major center for money-laundering, prostitution, and drug trafficking (Tan, 2014; Swe and Chambers, 2011, p. 85). SEZ in Cambodia and Laos have certainly become new international trading nodes, but this has not led to local development.

On the other hand, the Thai government uses the GMS as an extra tool for developing its outlying provinces and decongesting the Bangkok metropolitan area (Swe and Chambers, 2001; Tsuneshi, 2008; Lainé, 2014). It favors the creation of twin border cities, investing massively in cross-border transport infrastructure: a cross-border bridge like the "friendship bridge" between Nong Khai in Thailand and Thanaleng near Vientiane, the capital of Laos, or cross-border bus lines, both aiming to facilitate border crossing. It is also investing directly in the creation and development of SEZ. However, in spite of tax exemptions and preferential loans for firms choosing to decentralize their activities more than 150 kilometers from Bangkok, the effect of this border industrialization policy is still limited: the Chiang Rai SEZ, the country's first, or the Mukdahan logistics center and industrial zone are having difficulty taking off. The only 
exception is the Mae Sot SEZ on the Burmese border: it attracts industries on account of the low cost of Burmese labor, which represents the majority of the workforce, and its easy access to Bangkok.

\section{Differential Benefits for Different Social Groups}

A road undeniably provides the possibility for local populations to integrate a market economy, although this possibility does not always become a reality and can also produce differential benefits for different social groups. In her study of the social differences brought in northern Laos by the construction of National Road 3, a part of the Northern Economic Corridor, V. Bouté (2014) shows that not all populations are able to benefit from the road since pressure on land is increasing and a large sum is needed for initial investment. Only traders and the local urban elite, already well established, have been able to buy rubber plantations and thus benefit from the impact of the North-South economic corridor crossing the province of Luang Namtha, whereas new migrants, farmers from the highlands, have become impoverished. The work of Thein Swe and Paul Chambers (2011) shows that the road has led to the emergence of new social, economic, and environmental problems (illegal trade in wood and animals, spread of HIV/Aids and prostitution), as well as a mass displacement of Chinese to neighboring countries that is an increasing worry to local populations. They quote the words of Preecha Kamolbutr, the governor of Chiang Rai province: "Chinese businessmen come in with their own capital, their own workers and their own construction materials. I fear that in the future the Lao people might feel that they've been exploited. They will feel they've been invaded"' (p. 91).

In northern Laos, the opening of the border and the road favored the installation of foreign concessions, mostly Chinese, investing mainly in the agricultural sector (rubber, maize, and tea). These plantations have not only replaced dry agriculture or cultivation on burnt land but may lead to a change in the region's socioeconomic environment. Laotian farmers provide land and labor, and Chinese firm capital, technology, and market access. Danielle Tan (2014), however, shows that this system of "contract farming" is changing to that of a "concession model": since Laotian labor is not sufficient, it is beginning to be replaced by workers from China. By thus conceding the right to use their land or by being dispossessed by foreign investors, Laotian farmers risk being excluded from any participation in the rural development policy of northern Laos; they may continue to own the rights to their land, but they may no longer take decisions regarding its use. Following the massive influx of Chinese migrants, Laotian traders have also lost their role of middlemen: they have been evicted from the sugarcane trading network and also goods transport networks, and Chinese markets are beginning to supplant Laotian ones. The North-South economic corridor has certainly favored the agricultural development of northern Laos, but this is taking place, at best, with small benefit to the local population and, at worst, to their detriment.

The perception of the road by the local population is also an important, but often neglected factor for understanding these individual strategies. It leads to the migration of peasants from the highlands to the lowlands against all economic reason since the road is a symbol of modernity and development. V. Bouté (2014) describes how villagers have moved closer to roads while enclaved villages are gradually disappearing. This strong rural mobility, brought about both by coercive government measures and by the attractiveness of new habitats situated along the roads, has profoundly changed the social composition of plains villages. The perception of the road may also be completely out of phase with that of the ADB and 
government planners, for whom the road is always associated with the idea of progress. For the population of the Sepon district in Savannakhet province in southern Laos, V. Pholsena (2014) shows that Road 9, damaged by years of conflict, is above all associated with memories of past barbarity and atrocities. Its rehabilitation is seen by the local population as a means of reconstruction and reconnection with civilization, and the road has become the symbol of a possible rebirth. Multiple factors also have to be taken into account when analyzing the impact of road construction on local society since "there is more to roads than social engineering projects, economic growth or security control" (Pholsena, 2014).

\section{Conclusion}

This chapter shows that there is no mechanical effect between the growth of transport flow and economic development, and this is true at all levels. A corridor may facilitate exchanges but if there are no goods to export and no market, it remains a mere transport route, a simple axial road. Of course, without transport there can be no exchange of goods, but exchanges also, and sometimes mainly, depend on many other factors: the manufacturing capacity of different areas, production costs, tariff and legal barriers, specific demand, and so on. Infrastructure building just provides new opportunities, but the reality of its economic impact depends on many factors: the strategies of international organizations such as the ADB, policies implemented by national governments, or capacity of adaptation of local populations. The success of certain spatial strategies, for example, economic corridors in mainland Southeast Asia or SEZ in Thailand, cannot be duplicated with similar success in other territories: corridors are not suited to the operation of maritime areas, and SEZ in Cambodia and Laos are merely enclaves unable to bring growth to their immediate environment.

It should also be emphasized that building new infrastructures may even play a negative role in territorial change. Enclosure is a protection from competition, and therefore, if accessibility improves, competition increases. The Indonesian government understands this: its reticence concerning greater involvement in the ASEAN connectivity plan is a means of protecting a still fragile economy. On the contrary, the opening of Laos to transnational infrastructures has certainly led to the opening up of this long-isolated territory, and increased integration into the world economy, but it has also directly contributed to an even greater marginalization of part of the Laotian population. According to the scale used, national or local, Laos is a winner or a loser of the development corridors. Each government has the task of anticipating the impact of building new transnational infrastructures by identifying the sectors and areas that may benefit or lose out.

At the very least, it is important to note that the term of "connectivity" has the advantage, for political actors, of erasing an important question, that of taking control of the integration process once interconnection between national networks has been achieved. However, infrastructures, corridors, and the regionalization networks that they create are, like territories, stakes of power: between China and Japan, Thailand and Vietnam, and even between mainland and maritime Southeast Asia, competing for importance within ASEAN. The term "connectivity" used in the MPAC does not seem to take into account the increased competition between territories either: the plan for improving sea links between the ports of maritime Southeast Asia is certainly a means of promoting better regional integration but it takes little account of the major role of the shipping companies, which alone decide whether or not to use a port, and the growing competition between ASEAN ports to capture international traffic. 
Conciliating internal connectivity within ASEAN and external connectivity is not lacking in contradictions and difficulties.

\section{Bibliography}

ASEAN. 2011. Master Plan on ASEAN Connectivity. Jakarta: ASEAN Secretariat.

Asian Development Bank. 1999. Economic Cooperation in the Greater Mekong Subregion; An Overview. Manila.

- 2007. Indonesia-Malaysia-Thailand Growth Triangle, Building a Dynamic Future, a Road Map for Development 2007-2011. Philippines.

. 2012. BIM-EAGA, Implementation Blueprint 2012-2016.

Bafoil, F. 2013. "Capitalisme politique et développement dépendant en Asie du Sud-Est," Revue de la régulation, http://regulation.revues.org/10103.

Banomyong, R. 2006. Logistics Development Study of the Indonesia-Malaysia-Thailand Growth Triangle (IMT GT), Thammasat University, Bangkok.

Banomyong, R., P. Varadejsatitwong, and N. Phanjan. 2011. "ASEAN-India Connectivity: A Thailand Perspective," in F. Kimura and S. Umezaki (eds.), ASEAN-India Connectivity: The Comprehensive Asia Development Plan, Phase II. Jakarta: ERIA, 205-42..

Basu Das, S. 2013. Enhancing ASEAN's Connectivity. Singapore: Iseas.

Bender, S. 2001. "Trade Corridors: The Emerging Regional Development Planning Unit in Latin America," in D. Edgington, A. Fernandez, and C. Hoshino (eds.), New Regional Development Paradigms, vol. 2, New Regions, Concepts, Issues and Practises. Greenwood Press.

Bouté, V. 2014. "Population's Mobility in Northern Laotian Transborder Areas," in N. Fau, S. Khonthapana, and Ch. Taillard, Transnational Dynamics in Southeast Asia, The Greater Mekong Subregion and Malacca Straits Economic Corridors. Singapore: ISEAS, 399-421.

Charras M. 2014. "Sumatra Transnational Prospect beyond Indonesian Integration," in N. Fau, S. Khonthapana, and Ch. Taillard, Transnational Dynamics in Southeast Asia, The Greater Mekong Subregion and Malacca Straits Economic Corridors. Singapore: ISEAS, 221-51.

Economic and Social Commission for Asia and the Pacific (ESCAP). 2009. Major Issues in Transport: Transport Infrastructure: Development and Operationalization of Dry Ports and Intermodal Transport Corridors.

Economic Research Institute for ASEAN and East Asia (ERIA). 2010. ASEAN Strategic Transport Plan 2011-2015.

Eswaran P. 2008. Enhancement of Sibregional Cooperation in BIMP-EAGA and IMT-GT. Manila.

Fau, N. 2014a. "Definitions and Problematics of Transnational Dynamics," in N. Fau, S. Khonthapana, and Ch. Taillard, Transnational Dynamics in Southeast Asia, The Greater Mekong Subregion and Malacca Straits Economic Corridors. Singapore: ISEAS, 3-22.

—. 2014b. "Maritime Corridors, Port System and Spatial Organization in the Malacca Straits," in N. Fau, S. Khonthapana, and Ch. Taillard, Transnational Dynamics in Southeast Asia, The Greater Mekong Subregion and Malacca Straits Economic Corridors. Singapore: ISEAS, 53-84.

Fau, N., S. Khonthapane, and Ch. Taillard (eds.). 2014. Transnational Dynamics in Southeast Asia: The Greater Mekong Subregion and Malacca Straits Economic Corridors. Singapore: ISEAS.

Htun, K. W., N. N. Lwin, T. H. Naing, and K. Tun. 2011. "ASEAN-India Connectivity: A Myanmar Perspective," in F. Kimura and S. Umezaki (eds.), ASEAN-India Connectivity: The Comprehensive Asia Development Plan, Phase II. Jakarta: ERIA, 151-203.

Ishida, M. (ed.). 2013a. Border Economies in the Greater Mekong Subregion. Palgrave Macmillan. . 2013b. "What Is the Cross-Border Transport Agreement (CBTA)?," in M. Ishida (ed.), Border Economies in the Greater Mekong Subregion. Palgrave Macmillan, 53-7.

Kimura, F. 2013. "The Development of Logistics Infrastructure in ASEAN: The Comprehensive Asia Development Plan and the Post-AEC Initiative," in S. Basu Das, Enhancing ASEAN's Connectivity. Singapore: ISEAS, 37-58. 
Kimura, K., and S. Umezaki. 2011. ASEAN-India Connectivity: the comprehensive Asia Development Plan, Phase II. ERIA Research, Jakarta.

Lainé, E. 2014. "Mukdahan and Savannaket, Internationalization Process of Twin Mekong Border Citues on the East-West Economic Corridor," in N. Fau, S. Khonthapana, and Ch. Taillard, Transnational Dynamics in Southeast Asia, The Greater Mekong Subregion and Malacca Straits Economic Corridors. Singapore: ISEAS, 338-60.

Min, A., and K. Toshihiro. 2012. "Newly Emerging Industrial Development Nodes in Myanmar: Ports, Roads, Industrial Zones along Economic Corridors," in Emerging Economic Corridors in the Mekong Region (pp. 187-230), edited by Masami Ishida, BRC Research Report No 8, Bangkok Research Center, IDE-JETRO, Bangkok, Thailand.

Pholsena, V. 2014. "There Is More to Road: Moderniy, Memory and Economics Corridors in Huong HoaSepon Lao-Vietnamese Border Area," in N. Fau, S. Khonthapana, and Ch. Taillard, Transnational Dynamics in Southeast Asia, The Greater Mekong Subregion and Malacca Straits Economic Corridors. Singapore: ISEAS, 379-98.

Shiraishi, M. 2013. "East-West Economic Corridor: Lao Bao-Dansavanh Border," in M. Ishida (ed.), Border Economies in the Greater Mekong Subregion. Palgrave Macmillan, 133-62.

Susantono Bambang. 2013. "Challenges for Building Better Transportation Infrastructure Linkages across ASEAN: Indonesia's Perspective towards an Integrated Asian Economic Community," in S. Basu Das, Enhancing ASEAN's Connectivity. Singapore: ISEAS, 59-71.

Swe Th, and P. Chambers. 2011. Cashing in across the Golden Triangle. Chiang Mai: Mekong Press. Taillard Ch. 2014. "The Continental Grid of Economic Corridors in the Greater Mekong Subregion Towards Transnational Integration," in N. Fau, S. Khonthapana, and Ch. Taillard, Transnational Dynamics in Southeast Asia, The Greater Mekong Subregion and Malacca Straits Economic Corridors. Singapore: ISEAS, 23-53.

Tan, D. 2014. "'Small Is Beautiful': Lessons from Laos for the Study of Chinese Overseas.” Journal of Current Chinese Affairs 41, 2.

Tsuneshi, T. 2008. Development of Border Economic Zones in Thaïland: Expansion of Border Trade and formation of Border Economic Zones. IDE Discussion. JETRO.

Vignat, E. 2014. "Shan State in Myanmar's Problematic Nation-Building and Regional Integration : Conflict and Development," in N. Fau, S. Khonthapana, and Ch. Taillard, Transnational Dynamics in Southeast Asia, The Greater Mekong Subregion and Malacca Straits Economic Corridors, Singapore: ISEAS, 191-221.

Wade, G. 2010. “ASEAN Divide,” New Mandala. http://asiapacific.anu.edu.au/newmandala/wpcontent/uploads/2010/12/Wade-ASEAN-Divides.pdf. 